\title{
ДА ЛИ ЈЕ ЈАПАН ЦРНА РУПА КУЛТУРЕ?
}

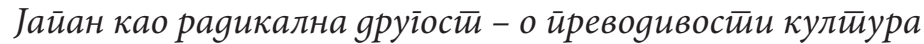

Овај рад бави се питањем преводивости култура анализирајући проблеме са којима се Западњаци суочавају покушавајући да појме културу Јапана, која се због своје суштинске gруїостии често налази на самој граници појмљивости и преводивости. У раду се највећим делом ослањамо на спознаје истраживача садржане у одабраним радовима из збор-

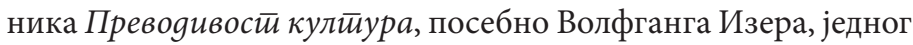
од приређивача зборника, о начелној могућности превођења култура. Закључке из радова у овом зборнику проверавамо анализирајући релевантне аспекте рецепције филма Софије Кополе Изіу бљљени у йревоgy, који је био предмет контроверзи када се ради о односу Западњака према култури Јапана.

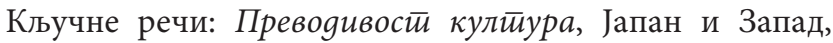
другост, Волфганг Изер, Изі̄ублени у йревоgy, Софија Копола.

Провокативна теза из наслова овог рада плод је детаљне анализе изложене у раду Карла Лудвига Фајфера (Karl Ludwig Pfeiffer) објављеном у зборнику радова о преводивости култура (The Translatability of Cultures, 1996) који су приредили Сенфорд Будик (Sanford Budick) и Волфганг Изер (Wolfgang Iser). Духовито заоштривши своју тезу у самом наслову рада „Црна рупа културе: Јапан, радикална другост и губљење разлике (илити, „У Јапану је све нормално”) (Budick \& Iser 1996: 186-203) - Фајфер у своме раду анализира један гранични случај преводивости култура. Његов избор није нимало изненађујући: наиме, ако су културе уопште преводиве, онда 
се њихова преводивост најпоузданије доказује на примерима култура које су због својих особености и суштинске gруїостии на самој граници преводивости. То је свакако случај са Јапаном: амерички социолог културе Симор Мартин Липсет (Seymor Martin Lipset) сврстава Јапан међу земље које назива outliers (Lipset 1993: 122). Термин outlier у статистици означава вредност или појаву која у великој мери одступа од просека. Јапан то свакако јесте, о чему речито сведочи мноштво научних радова о овој далекоисточној земљи који, са мање или више успеха, покушавају да особености јапанске културе објасне Западњацима. Променљиви успех оваквих подухвата у правилу је био директно пропорционалан успешности са којом су истраживачи превазилазили ограничења западњачке културне перспективе.

Примера ради, не тако давно у радовима о култури Јапана могла су се прочитати и оваква запажања: „Јапан више није пустињак Истока, већ најзападнија од нација Запада" (Pfeiffer 1996: 186). Или:

Јапанац је у потпуности источњачки настројен у својим задовољствима, колико год он следио Запад у својим амбицијама.

Јапанци у дубини душе уистину мрзе Запад, али довољно су проницљиви да уоче да ниједна нација не може бити сила првог реда уколико не носи панталоне.

Закључак: постоји, уопште узев, мора се признати, некакав метод у јапанском лудилу, али он се заиста чини веома лудим светском путнику који није склон размишљању. (Pfeiffer 1996: 186)

Премда су савремене студије културе прешле веома дуг пут од момента када је, пре нешто више од једног века, Даглас Слејден (Douglas Sladen) изрекао ове прилично апсурдне опсервације о култури Јапана, тешко је отети се утиску, како резигнирано закључује Фајфер, да између оваквих безнадежно аматерских покушаја „транскултуралног разумевања" и озбиљне дескрипције култура једва да има неке разлике у принципу. Такве разлике посебно је тешко уочити код аутора који су због обиља својих „интеркултуралних” искустава склони наглашеним тврдњама (Pfeiffer 1996: 187). 
Што је најинтересантније, овакви парадокси као да важе не само за случајеве културних разлика, што би се по природи ствари дало и очекивати, већ и када се ради о уочавањима фундаменталних сличности међу културама. Рецимо, Карл Маркс је запазио да између Јапана из шездесетих година деветнаестог века и средњевековне Европе постоје изненађујуће сличности: „Јапан, са својом чисто феудалном организацијом земљишних поседа и својом развијеном petite culture, нуди нам много вернију слику европског Средњег века него све наше историјске књиге" (Pfeiffer 1996: 187). При томе, од малог је значаја, како изгледа, што Маркс никада није био у Јапану, будући да та земља, према многима који у њој боравили, у правилу постаје у већој, а не у мањој мери, енигматична што дуже човек борави тамо (Pfeiffer 1996: 187).

И нису само Западњаци фасцинирани Јапаном и његовом „радикалном другошћу”: и саме Јапанце фасцинирају расправе о њиховој „јединствености” (Nihonron), јапанском пандану америчкој изузетности. У својој студији о америчкој изузетности (American Exceptionalism, 1996), Симор Мартин Липсет позива се на оцену Питера Дејла (Peter N. Dale) да се „литература о јапанском идентитету темељи на стално понављаном рефрену о јединствености". На основу једног прегледа литературе о јапанској јединствености процењује се да је више од две хиљаде студија посвећено овој теми објављено после Другог светског рата до почетка деведесетих година двадесетог века (Lipset 1997: 212). Симптоматично је, пак, да је студија Питера Дејла на коју се Липсет позива насловљена Мити о јайанској јеgинсиивеностии (Myth of Japanese Uniqueness, 1986) (Lipset 1997: 325). Присуство речи „мит” у наслову Дејлове студије речито упозорава на то да ваља са крајњом опрезношћу приступати проучавању култура различитих од наше, нарочито оних „радикално другачијих”, јер се питање преводивости култура и доживљаја култура у таквим ситуацијама појављује у најзаоштренијем виду. Стога не изненађује што практично сви аутори заступљени у поменутом зборнику о преводивости култура на питање о томе да ли је то практично могуће својим радовима одговарају: „Начелно да, али...”. Сумирајући резултате овог замашног 
истраживачког подухвата, приређивачи зборника Сенфорд Будик и Волфганг Изер чак износе оцене о „кризи алтеритета" (Budick 1996: 1), као и да је сваки напор усмерен на превођење култура неизбежно обележен трачком непреводивости, односно, да се узајамно разумевање култура увек суочава са одређеним степеном несамерљивости међу њима (Iser 1996: 301), о чему ће касније бити више речи.

Ових инхерентних ограничења очито данас мора бити свестан сваки изучавалац културе и културне компаратистике када се упушта у увек неизвесни посао тумачења културних карактеристика и њиховог превођења. Како упозорава Карл Лудвиг Фајфер, „превођење”, било да се ради о језичком или превођењу култура, представља једну од важних метафора на којима се темељи наш живот. Она полази од претпоставке, не само интуитивно уверљиве, да текстови имају значења, да културе поседују идентитете који се у великој мери могу дефинисати на основу акумулираних значења. Та значења могу бити производ историјских традиција, националних или групних веза и афинитета, импликација ритуала и томе слично. У оваквој мисаоној конструкцији, превођење нема за циљ интегрално очување тих мање или више фиксираних или флуидних културних идентитета. Њиме се разабиру структуре кореспонденција и различитости, које пажљивим тумачењем ваља разликовати и одвојити од присвајања, деформисања, подјармљивања или чак уништавања другости, до чега је често долазило у стварним историјским околностима (Pfeiffer 1996: 187-188).

У овом контексту треба се присетити упозорења Ролана Барта (Roland Barthes) из студије Царстиво знакова (Lempire des signes, 1970) да Истоку и Западу не приступа као „стварностима” које ваља супротставити историјски, филозофски, политички или културолошки, да не посматра суштину Оријента (која, ако је веровати стручњацима, ионако не постоји због огромних разлика између, на пример, Кине и Јапана) ${ }^{1}$ очима његовог великог поклоника, већ

1 Уистину, Семјуел Хантингтон (Samuel Huntington) у својој утицајној

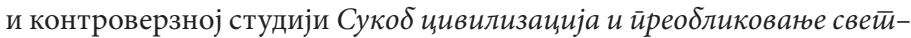

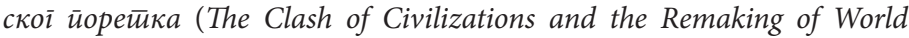


да посматрајући Јапан као царство празних знакова тражи пукотине у симболичком поретку (Pfeiffer 1996: 188-189). И налази их - премда не превасходно на јапанској страни. Истина је, како примећује Фајфер, да прихватање онога што Барт говори о Јапану као да у знатној, истини за вољу - неодредивој мери зависи од симпатије или антипатије коју човек осећа, гледано из било које перспективе, према (слојевима или сегментима) јапанске културе. Осим тога, ако у његовом тексту има дескриптивне прецизности, а има је, каже Фајфер, узимајући у обзир наше западњачке стандарде, свакако у великој мери, Бартов текст у том светлу делује као носталгичан, или пак антиципаторски, опис онога чега су многи постали свесни као мањкавости или терета западних културних традиција (Pfeiffer 1996: 189). Тако је, примера ради, западњачка кухиња, ако је веровати Барту, усредсређена на доминацију, „пенетрацију” хране (због важности ножа и виљушке и одређених начина њихове употребе), док је јапанска кухиња, насупрот томе, посвећена умећу „нутриционистичког круга”, где „нежна” употреба штапића за јело доприноси целовитости нивоа животних процеса (Pfeiffer 1996: 189).

Шта год човек мислио о Бартовом начину размишљања, вероватно ће се сложити са Фајферовом оценом да његова књига спада међу најрафинираније и недогматске видове културног дискурса који покушава да пренесе осећај културне разлике не упадајући у замку њене референцијалности (Pfeiffer 1996: 190). Извесно је да већину радова из домена модерне „јапанологије” не одликује софистицираност какву показује Барт у својој анализи. Уистину, рад који вероватно представља класичну студију о Јапану из перспективе културне антропологије, књигу Рут Бенедикт (Ruth Benedict) Хризаниемема и мач: модели јайанске кулйуре (The

Order, 1997) сврстава Кину и Јапан у две различите азијске цивилизације, напомињући да, премда неки изучаваоци сврставају јапанску и кинеску културу у оквире једне далекоисточне цивилизације, већина њих посматра Јапан као јасно издвојену цивилизацију потеклу од кинеске, која се формирала између 100. и 400. године нове ере (Huntington 2003: 45). 
Chrysanthemum and the Sword: Patterns of Japanese Culture, 1946), карактерише екстремно класификаторски приступ, мноштво листа културних датости, а нарочито шематски приказ обавеза Јапанаца и њихових различитих дужности, укључујући ту и осећања, према разним врстама референтних група. Према речима Езре Ф. Вогела (Ezra F. Vogel), познаваоца јапанске културе, студија Бенедиктове приказује Јапанце као одвећ круте, превише спутане разним дужностима и друштвеним положајем, претерано заокупљене сопственом репутацијом (Pfeiffer 1996: 190). Томе је несумњиво допринела чињеница да је ова студија рађена под не малим притиском историјског тренутка у коме је настала. Како сама Бенедиктова открива, њој је јуна 1944. „стављено у задатак” да проучи Јапан. У поодмаклој фази борби на пацифичком ратишту, разуме се, требало је сазнати што више о моралу Јапанаца: зашто су били спремни да се боре када је било очито да губе рат, зашто би радије погинули него да буду заробљени, зашто су неки од њих, када су ипак били заробљени, у изузетно великој мери сарађивали са Американцима, а у општијем смислу, зашто су и веома учтиви и истовремено веома брутални, и покорни и иновативни, и налик роботима по свом понашању и креативни, и тако даље.

Но, и у каснијим научним радовима, који нису били тако очигледно мотивисани потребом за „стратешким” знањима о култури Јапана, опстајала је интелектуална потреба за долажењем до културних датости које сежу даље од акумулираних тумачења. Тако, рецимо, премда немачка јапанолошкиња Ирмела Хиђија-Киршнерајт (Irmela HijiyaKirschnereit) у својој студији Крај еїзойике (Das Ende der Exotik, 1988) тврди да је дошао крај „егзотизацији” Јапана, њени описи друштвених и културних улога жена у Јапану нераскидиво су повезани са идеологијом датости културних структура (Pfeiffer 1996: 191).

„Задаци” попут оног који је пред крај Другог светског рата добила Рут Бенедикт, а не треба губити из вида чињеницу да академске студије лако могу бити резултат неутрализоване институционализације таквих задатака, доприносе учвршћивању идеје да културе ваља проучавати као ентитете, 
а не као појаве које треба посматрати и са њима бити у интеракцији. Међутим, искушење да се културни модели, а тиме и културне разлике, посматрају мање-више као датости не може опстати данас, како истиче Фајфер, када се суочава са застрашујућом масом самореферентних понављања и чињеницом да контрадикције практично аутоматски извиру из културног дискурса, што намеће потребу за методолошким преоријентисањем. Одатле се лако стиже до идеје да културе нису ништа друго до слике и стереотипи утемељени на некаквој празној реалности, али и она тешко може опстати у суочавању са веома далеким, туђим, а отуда и интелектуално подстицајним културама (Pfeiffer 1996: 191-192).

Тако, када Жан-Пјер Леман (Jean-Pierre Lehmann) у својој књизи Слика Јайана: og феуgалне изолованостии gо свеиске силе, 1850-1905 (The Image of Japan: From Feudal Isolation to World Power, 1850-1905, 1978) говори о сликама „модернизације”

Јапана у наведеном периоду (или се ту пре ради о вестернизацији, позападњавању? - ова дистинкција уопште није једноставна), он помиње „културне инвазије” и „увоз” од петог века наовамо као да су инвазије и увоз једно те исто, или као да је њихов утицај могуће јасно сагледати (Pfeiffer 1996: 192). А и сам појам „култура” је доживео семантичку еволуцију, дотеривања, апстракције и реконкретизације разних врста у различитим „културама”. Пошто у таквој ситуацији било шта, колико год да је тривијално, може постати културни симбол, рекло би се да је једнакост или подударност нивоа или слојева различитих култура веома мало вероватна (Pfeiffer 1996: 194).

Стога је парадоксално што се дешава да јапанска култура, и поред не малих разлика од било које културе Запада, појединим Западњацима улива осећање „психолошке сигурности” или чак „осећај припадања” иако у њој никако не могу истински партиципирати (Pfeiffer 1996: 194-195). Примера ради, британски културни аташе Ерик Томлин (Eric W. F. Tomlin), који је провео неколико година у Јапану, у својој књизи Послеgюа земља: моје іооине у Јайану (The Last Country: My Years in Japan, 1978) не устеже се да изнесе тврдњу да се у Јапану „осећате ближим суштини ствари. Осећате да постоји 
природан живот и природан поредак ствари, који су, уз стално обнављање и санкционисање, извор и предуслов људске среће”. А Герхард Кајзер (Gerhard Kaiser), германиста из Фрајбурга, разматрајући у сличном духу искуство јапанског Но театра, који је утицао на бројне европске ствараоце, закључује да „посматрајући туђе, ми заправо посматрамо потенцијале себе самих. За посетиоца из Европе, живље од присећања на културну спознају је предосећање да ће га по повратку у Немачку испуњавати осећање носталгије за Јапаном" (Pfeiffer 1996: 195). Овакав језик, колико год се чинио немогућим, указује Фајфер, одражава парадоксални нестанак разлике у контексту њеног најснажнијег присуства (Pfeiffer 1996: 195).

Томлиново објашњење овог парадокса, „ако је то уопште парадокс”, гласи да „ова солидарност заједнице, ова помало интровертна форма друштва, не отуђује странца већ га привлачи". Наравно, не сваког странца, додаје Фајфер, и у мањој мери стране жене него мушкарце (Pfeiffer 1996: 195). Тврдње о „радикалној другости” Јапана, како изгледа, срећу се готово исто тако често као и спознаје о суштински заједничким карактеристикама које јапанска култура дели са културом Запада, односно, барем са неким њеним сегментима. Због тога се стиче утисак да покушаји поређења ове две културе западају у ћорсокак када настоје да уобичајеним компаративним методима концептуализују било радикалну другост било нестајање разлике међу њима (Pfeiffer 1996: 196). Чини се да управо помињани Ерик Томлин нуди барем део решења овог парадокса. Наиме, решење ове дилеме умногоме зависи од тога да ли је могуће успоставити појмовно чврсто утемељену разлику између „аутентичног” и „позападњаченог” Јапана. Ако је веровати Томлину, „никада није постојао аутентични Јапан који истовремено није био и Јапан жељан асимиловања спољашњих утицаја. То је аутентични Јапан” (Pfeiffer 1996: 195). Како закључује Фајфер, периоди наизглед готово потпуне изолованости Јапана, која је потрајала више од две стотине година под династијом Токугава, и свеобухватне вестернизације Јапана, која је уследила у периоду династије Меиђи, представљају напросто крајње положаје клатна које описује развој културе ове далекоисточне земље. Јер, практично је немогуће успоставити 
разлику између културе Јапана и онога што представља њен „увозни” део, било да се ради о последицама страних утицаја или инвазија. Овакве осцилације културног клатна начиниле су од Јапана огледни случај и трајни изазов теорији културе и њеној семантици (Pfeiffer 1996: 195-196).

У сваком случају, и поред каткада изненађујућих осећања блискости и заједништва које поједини Западњаци исказују спрам културе Јапана, у стручној литератури и у лаичкој перцепцији истрајно опстаје утисак о томе да је јапанска култура радикално другачија од других. Примера фрустрирајућег неразумевања у културном искуству како Јапанаца тако и gaijin (странаца) свакако има у изобиљу. Чињеница да се то дешава у тривијалним ситуацијама из свакодневног живота, али исто тако често и у расправама интелектуалаца, подстакла је код не малог броја Западњака осећање да су такве културне размене празне будући да готово легендарна радозналост Јапанаца, коју Фајфер назива „митским културним џокером”, у културној размени жудно апсорбује све а не враћа ништа. Отуда је прилично распрострањено схватање о Јапану као својеврсној црној рупи културе, која, попут црне рупе из астрономске науке, прождире све што уђе у њено културно поље гравитације, где остаје занавек заробљено (Pfeiffer 1996: 198). О томе, рецимо, у неким својим радовима говори познати француски јапанолог Огистен Берк (Augustin Berque) (Pfeiffer 1996: 336).

Оваквим схватањима као да иде у прилог културно искуство протагониста популарног филма редитељке Софије Кополе (Sofia Coppola) Изїубльени у йревоgy (Lost in Translation, 2003). Двоје Американаца, средовечни глумац Боб и млада Шарлота, која је дипломирала филозофију, осећају се безнадежно изгубљеним у Токију, мегалополису културе која је обома сасвим туђа. Њихово осећање изгубљености произлази из језичке и културне баријере, углавном непремостиве, која их раздваја од околине. Премда то у њима најчешће подстиче осећање меланхолије, њихова изгубљеност и неприлагођеност околини често поприма комичне тонове, и управо је уметнички веома успели спој хумора и меланхолије, рекли бисмо, оно што на гледаоца оставља најдубљи утисак и доприноси естетској вредности филма. 
Примера ради, комични проблеми са којима се Боб суочава када покушава да се истушира у купатилу своје хотелске собе (висина туша прилагођена је просечној висини Јапанаца, тако да је Боб приморан да се сагиње како би се истуширао) пластично илуструју антрополошке разлике између Јапанаца и Западњака, које представљају само један аспект много свеобухватнијих културних разлика и особености. Језичка баријера, пак, у великој мери спутава комуникацију са околином. Када, током снимања рекламног спота за јапанску телевизију, редитељ веома детаљно објасни Бобу шта се од њега очекује, а Јапанка која му преводи то сведе на једну једину кратку реченицу, Боб зачуђено пита: „Је ли само то рекао?”.

Међутим, двоје Американаца нису изгубљени само „у преводу”, односно, због помањкања смислене језичке комуникације и културне интеракције. Они су такође изгубљени у сопственим животима и браковима, будући да са одвијањем радње филма постаје све очигледније да њиховим браковима предстоје бродоломи. Ова чињеница још их болније погађа због културне и језичке дислоцираности, и њихови заједнички јади довешће до њиховог краткотрајног зближавања. Но, њихова блискост, коју редитељка приказује са много суптилности и саосећања, само накратко потискује болне чињенице њихових живота у други план: њихов растанак на крају филма, како се чини, коначан је, и означава повратак из стања „изгубљености у преводу” у отуђеност сопствених живота и бракова.

Очигледни јаз који раздваја западњачку и јапанску културу у овом филму подстакао је одређена размимоилажења у критичкој рецепцији филма, која шире гледано представљају речито сведочанство о инхерентним проблемима интеркултуралне комуникације и превођења култура. Док су западњачки критичари углавном веома похвално оценили филм (није мањкало номинација за Оскара, Софија Копола добила га је за најбољи сценарио), више јапанских критичара сматра да је Кополин приказ савременог Јапана и Јапанаца увредљив, будући да она у свом филму Јапанце приказује као људе достојне подсмеха који су изгубили контакт са сопственом културом (Anon 2016).

Тврдња да су Јапанци без изузетка приказани као народ искључиво достојан подсмеха напросто не може издржати 
било какву озбиљнију анализу порука које нам овај филм шаље између редова. Ако је тачно да редитељка повремено збија шале на рачун Јапанаца, исто је тако тачно да и амерички протагонисти филма повремено изазивају подсмех својом неприлагођеношћу околини и мање или више неуспешним настојањима да се прилагоде. У оба случаја, смех који ауторка подстиче на рачун припадника обе културе незлобив је и добродушан. У овом контексту не треба заборавити да предмет највећег подсмеха у филму није ниједан од јапанских ликова, већ америчка глумица која кад год проговори - изваљује непојамне глупости.

Премда је истина да Боб и Шарлота практично немају никакву смислену комуникацију са Јапанцима, већ је она сведена на баналности свакодневног општења са околином, то није због тога што њима до такве комуникације није стало, већ зато што јој стоје на путу прирођена ограничења интеркултуралне комуникације, пре свега она језичког карактера. Боб истински жели да сазна детаље који се изгубе у преводу, али за та сазнања у правилу остаје прикраћен. Шарлоту истински привлачи умеће икебане, али језичка баријера и осећање несигурности у околини која јој је туђа спречава је да у прављењу цветних аранжмана учествује на начин који би је одиста испуњавао. Критичари склони да у осујећености смислене интеркултуралне комуникације у овом филму виде културни расизам заборављају да је кључни елемент филма однос Боба и Шарлот, то јест, изненадна и дубока блискост две прилично изгубљене западњачке душе, а она је уметнички уверљива управо због њихове наглашене отуђености у односу на околину, због чега је инсистирање на чињеници до које је мере Токио стран главним ликовима од кључног значаја за поруку филма.

Чак и из ове веома сведене анализе, видљиво је да филм Изі̄удљени у йревоgy на уметнички упечатљив начин сажима неке од најважнијих дилема везаних за јапанску културу и однос Западњака према њој. Оно што је карактерисало настојања како стручњака тако и лаика да појме суштину јапанске културе - мишљење да јапанска култура садржи нешто тајанствено, недокучиво, истрајава и у филму који 
приказује западњачки доживљај Јапана на почетку двадесет и првог века. Барем неке одговоре на питање зашто је то тако доноси нам зборник радова који се баве разматрањем принципијелне могућности преводивости култура, из кога смо се за сада највећим делом ослањали на анализу изненађујуће распрострањене тезе да је Јапан црна рупа културе из пера Карла Лудвига Фајфера.

Сводећи биланс вишегодишњег рада на пројекту истраживања сусрета различитих култура у смислу њихове преводивости, у коме су учествовали стручњаци из више земаља, Волфганг Изер наводи бројне ограде и резерве изнете у радовима садржаним у поменутом зборнику.

Пре свега, истиче Изер, потребно је размотрити значење

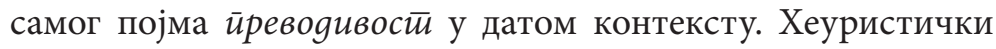
гледано, преводивост је свеобухватни појам који нам омогућава да разматрамо прожимање различитих култура а да при томе нужно не организујемо или класификујемо такве сусрете међу културама. Поред тога, појам преводивости покрива све врсте превођења, будући да се односи на скуп могућности које се селективно реализују у било ком конкретном преводу. Потпуни скуп могућности никада се не може сасвим реализовати у датом преводу, али ће нам омогућити да уочимо које могућности усмеравају дати превод, чиме се ствара свест о томе шта тај превод привилегује и у којој мери успостављене референце уобличавају позиције које се транспонују једна у другу (Iser 1996: 295).

Преводивост карактерише инхерентно двојство, будући да конотација у језику произлази из превођења дословног у фигуративно, при чему се дословно значење ограђује, али истовремено остаје видљиво како би давало смернице за померено значење које треба докучити. Другим речима, оно што је ограђено и не мисли се у датом тренутку користи се да би се оцртале контуре фигуративног. Изер ову замену позиција дефинише као својеврсну перформансу проистеклу из разлике између дословног и фигуративног (Iser 1996: 295).

На нивоу односа међу културама, показало се да је превођење култура историјски условљена операција у којој фигурира поменуто прирођено двојство преводивости. Оно 
се манифестује приликом рецепције традиције, које повлачи за собом преобликовање наслеђа; мапирање отворености културне садашњице чини да традиција постане периферна у односу на језгро које је сада од средишњег значаја; превођење са једне културе на другу резултира вишеструким спонама (Изер их назива „петљама”/loops/) између њих. У свим овим случајевима, поновно дефинисање разлике одражава односе међу културама и указује на оперативни потенцијал међупростора који их раздваја (Iser 1996: 296).

Како се показало у радовима из поменутог зборника, када је требало ближе одредити шта се дешава у односима између култура, доминантно место припало је појму узајамности. У најширем смислу, то је напросто размена међу културама типа „ја теби ти мени (give and take)”. Оно што је важније, међутим, јесте да се ту ради о међуодносу који у знатној мери чини оно што спаја. Будући да културе нису јасно дефинисане датости, а камоли холистички ентитети, њихови међусобни сусрети неизбежно резултирају узајамним обликовањем. Из те перспективе, узајамност се може сматрати конститутивном компонентом како културе тако и културне размене. Отуда су могући начини ближег одређивања односа међу културама, у које Изер убраја фузију, конверзију, асимилацију, апропријацију, допуштајући чак и синкретизам, такође и начини да се истакнуте карактеристике реификују тако што ће нека од њих бити издигнута до нивоа свеобухватног (umbrella) појма.

Но, узајамност, поред тога што обухвата све ове начине дефинисања културне размене, истовремено нам указује на то да не постоји нека трансцендентна позиција нити трећа димензија која би нам омогућила да концептуализујемо односе међу културама. Отуда узајамност указује на чињеницу да, када се неке културне карактеристике преводе међу културама, сваки такав напор обележен је трачком непреводивости, баш као што се и узајамно разумевање међу културама суочава са одређеним степеном несамерљивости, који заправо и подстиче напоре усмерене на разумевање. Стога је узајамност истовремено обележена непремостивим разликама и непрестаном тежњом да се граде мостови међу културама. Пошто нема 
начина да се појми непојмљиво и елиминише оно што се опире покушајима дефинисања, показује се да помињана реификација културних одлика представља средство помоћу кога се објашњава необјашњива разлика међу културама. Одбијање да се такво стање прихвати ствара осећање анксиозности из кога, у крајњем билансу, и проистичу ове реификације односа међу културама (Iser 1996: 301-302).

Спознаје до којих су дошли истраживачи укључени у подухват разматрања проблема преводивости култура, спроведен током прве половине последње деценије двадесетог века, омогућавају нам да јасније сагледамо положај јапанске културе на почетку двадесет и првог века. Са извесношћу се може рећи да Јапан засигурно није никаква „црна рупа”културе савремене епохе. Такав утисак може се стећи због чињенице да у односима између културе Запада и културе Јапана има доста тога што се може сврстати у оквире појма несамерљивости, о коме Изер говори као о незаобилазној компоненти односа различитих култура. Зато се није чудити, имајући у виду да и за стручњаке од заната разлике међу културама понекад представљају непремостиву препреку, што се двоје протагониста филма Софије Кополе осећају изгубљеним - и то не само у преводу. Њихово осећање изгубљености у окружењу културе радикално другачије од оне из које су потекли проистиче из њихове темељне погубљености у сопственим животима. Јаз међу културама само уметнички ефектно потенцира јаз који њих двоје дели од онога што у животу највише желе.

Уосталом, и Волфганг Изер признаје, закључујући свој резиме подухвата истраживања преводивости култура, да истраживачи који су се отиснули на пут ка интеркултуралном дискурсу, укључујући ту и њега самог, никада нису стигли до жељеног одредишта (Iser 1996: 302). Аутори радова у поменутом зборнику наводе бројне разлоге за то. Када је реч о томе зашто култура Јапана тако истрајно измиче настојањима како стручњака тако и лаика да је појме, Карл Лудвиг Фајфер у напола шаљивом напола резигнираном тону напомиње да се информације о некој култури често покажу веома варљивим управо када долазе од припадника саме те културе, истичући да управо његове јапанске 
колеге из академских кругова као да уживају да играју игре са Западњацима. Да ли је то резултат чувеног „релативизма" Јапанаца, њихове наводне невољности да се изјасне у прилог неког јасно дефинисаног става, њиховог ужасавања од конфронтација и несклоности експлицитним исказима, како наводи Роберт Кристофер (Robert Christopher) у својој студији Јайански ум (The Japanese Mind, 1983), или пак њихове враголасте склоности да вуку Западњаке за нос, чему је Фајфер, рекло би се, склон да верује (Pfeiffer 1996: 198), можемо у крајњем билансу само нагађати. Овако или онако, не треба губити из вида опомену Волфганга Изера да потреба за преиспитивањем односа међу културама, како изгледа, проистиче из осећања кризе: тема кризе присутна је у свим радовима у зборнику посвећеном преводивости култура. Уистину, чини се да је криза предуслов поимања да припадамо некој култури, да смо, како каже Изер, „уграђени (embedded)" у њу (Iser 1996: 302). Што је још важније, Изер као могући разлог за то што учесници пројекта истраживања преводивости култура нису стигли до жељеног одредишта - интеркултуралног дискурса, наводи чињеницу да истински интеркултурални дискурс изискује одређену дозу „самозатајности (self-effacement)”, потискивање себе у други план или барем привремено одустајање од сопственог става да би се саслушало шта други има да каже (Iser 1996: 302). А то је, како се чини, нешто што је мали број припадника било које савремене културе спреман да учини.

\section{Извори и литература}

Anon 2016: https://en.wikipedia.org/wiki/Lost_in_Translation_(film), приступано 30. 6. 2016.

Budick 1996: Budick, Sanford. „Crises of Alterity: Cultural Untranslatability and the Experience of Secondary Otherness". Sanford Budick, Wolfgang Iser (eds.). The Translatability of Cultures. Stanford, California: Stanford University Press, 1996. 1-22.

Budick \& Iser 1996: Budick, Sanford i Wolfgang Iser (ur.). The Translatability of Cultures. Stanford, California: Stanford University Press, 1996. 
Huntington 2003: Huntington, Samuel. The Clash of Civilizations and the Remaking of World Order. New York: Simon and Schuster, 2003.

Iser 1996: Iser, Wolfgang. „Coda to the Discussion”. Sanford Budick, Wolfgang Iser (ur.). The Translatability of Cultures. Stanford, California: Stanford University Press. 294-302.

Lipset 1993: Lipset, Seymor Martin. „Pacific Divide: American Exceptionalism - Japanese Uniqueness". International Journal of Public Opinion Research, Vol. 5 No. 2 (1993): 121-166.

Lipset 1997: Lipset, Seymor Martin. American Exceptionalism - A Double-Edged Sword, New York and London: Norton, 1997.

Pfeiffer 1996: Pfeiffer, K. Ludwig. „The Black Hole of Culture: Japan, Radical Otherness, and the Disappearance of Difference” (or „In Japan, everything normal"). Sanford Budick, Wolfgang Iser (ur.). The Translatability of Cultures. Stanford, California: Stanford University Press. 186-203.

\title{
Svetlana M. Petrović
}

\author{
IS JAPAN A BLACK HOLE OF CULTURE? \\ Japan as a Radical Second - About the Translatability of Cultures
}

\section{Resume}

This paper deals with the issue of cultural translatability by analyzing the problems that Westerners face in trying to understand the culture of Japan, which, because of its intrinsic otherness, is often at the very frontier of conceptuality and translatability. For the most part, the paper relies on the insights of researchers contained in selected works from the Proceedings of the Translator of Cultures, especially Wolfgang Iser, one of the compilers of the Proceedings, on the principle possibility of translating cultures. We draw conclusions from the papers in this volume by analyzing the relevant aspects of the reception of Sofia Kopola's film Lost in Translation, which has been the subject of controversy when it comes to the attitude of Westerners to the culture of Japan.

Key Words: Cultural Translatability, Japan and the West, Otherness, Wolfgang Izer, Lost in Translation, Sofia Kopola. 